\title{
Professor Bongani Mayosi: A legend in our time
}

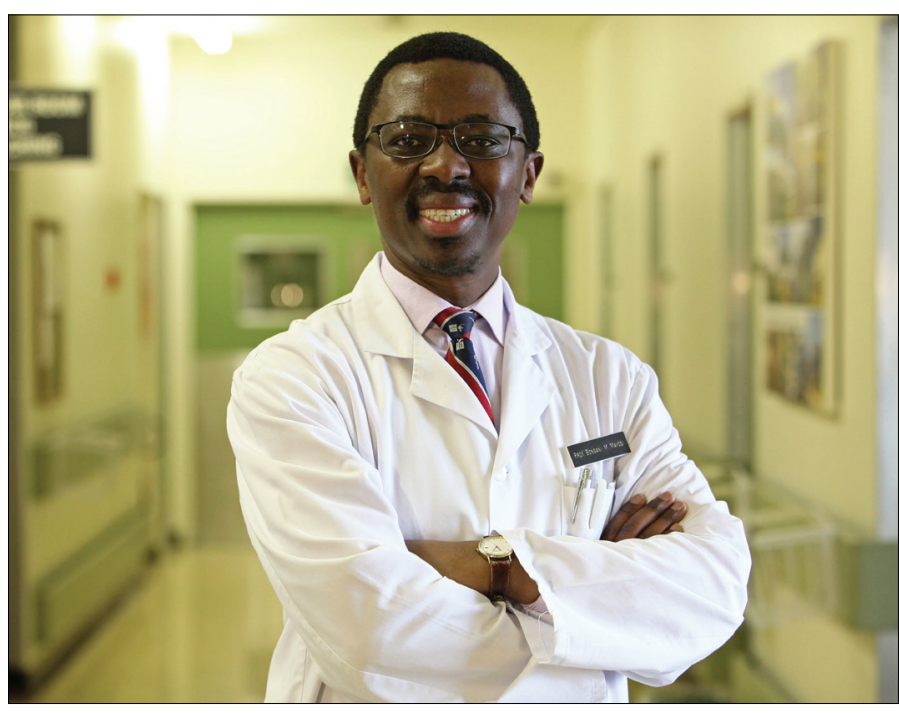

Bongani Mawethu Mayosi was born on 28 January 1967 in Mthatha, Eastern Cape, the second son of Dr George Sikhumbuzo Mayosi and Mrs Nontle Mayosi. He attended primary school in Upper Ngculu village, Ngqamakhwe, Eastern Cape. He completed his secondary schooling at the age of fifteen, matriculating from St John's College, Mthatha, and passing six subjects with distinction. His first two degrees were a BMedSci completed in 1986 and concurrently an MB ChB completed in 1989 at the University of KwaZuluNatal, both obtained cum laude and at the top of his class.

He worked as an intern at Livingstone Hospital in Port Elizabeth, then moved to Cape Town the following year to work as a senior house officer and later join the medical registrar rotation at Groote Schuur Hospital (GSH) and the University of Cape Town (UCT). Within three years he had been admitted to the Fellowship of the College of Physicians of South Africa. Immediately after this, he was awarded the prestigious Oxford Nuffield Medical Scholarship, allowing him to read for a DPhil in Cardiovascular Medicine on a project on cardiovascular genetics at the University of Oxford, under the supervision of Prof. Hugh Watkins. He returned from Oxford to complete his clinical training in cardiology at GSH and UCT. Thereafter, he worked as a consultant in the Cardiac Clinic. He was appointed as the seventh Chair and Head of the Department of Medicine at UCT and GSH in 2006. Following an illustrious tenure, during which he transformed the Department of Medicine, growing it to be the largest and leading medicine department on the African continent, in 2016 he was appointed as the Dean of the Faculty of Health Sciences at UCT and occupied this position until his untimely death on Friday 27 July 2018.

His enduring legacy will be one of research excellence, academic development and the transforming effect he had on individual lives, institutions and countries, particularly on the African continent.

His research focused on non-communicable diseases. He believed in a diversified portfolio of research, and projects of varying risk. For him, that portfolio included research on the epidemiology and genetics of heart muscle disease; heart failure; pathophysiology, clinical outcomes and genetics of rheumatic heart disease; tuberculous infections of the heart; HIV infection as it involves the heart; rare genetic disorders among
Africans; and strengthening of health systems in South Africa and on the African continent. When criticised by many that his research focus was too divergent, he always emphasised the important thematic linkage: he studied cardiovascular diseases of the poor - as he called them, 'the afflictions of the wretched of the earth'. It was his firm belief that by studying these diseases of pestilence, he could make his greatest contribution to the world.

During his career, he made seminal contributions to all these seven areas. He was considered the doyen of heart muscle disease on the African continent and has clarified the clinical profile, epidemiology and genetic basis of cardiomyopathies in Africans. Through this process he was involved in the discovery of many novel genes that cause sudden cardiac death and heart failure in Africans. In cardiovascular genetics, Prof. Mayosi's discoveries included genes causing dilated cardiomyopathy, hypertrophic cardiomyopathy, arrhythmogenic cardiomyopathy, coronary artery disease and hypertension. He established an internationally renowned laboratory at UCT, which at the time of his death was leading unique studies of the genetics of rheumatic heart disease and congenital heart disease in Africa. Among his contributions to knowledge in single-gene disorders, his discovery in 2017 of a new gene for arrhythmogenic cardiomyopathy was recognised as one of the most important medical advances made by a South African scientific team since the first human heart transplant. $\mathrm{He}$ has also provided the most complete investigation of the contemporaneous causes, clinical profile and optimal approaches to management of heart failure among Africans. He has advanced our understanding of the biology of rheumatic heart disease, the role of screening and the employment of a strategy of syndromic treatment of pharyngitis to prevent this disease in children. His research has influenced policy and guidelines on the management of this disease globally, and these have been adopted by the African Union, the World Heart Federation, the World Health Organization and the World Health Assembly. More recently, he advocated for the widespread availability of penicillin for the eradication of rheumatic heart disease in the global south. Through his investigation of tuberculosis in the heart, he clarified the appropriate diagnostic strategy and role of adjunctive steroids in tuberculous pericarditis. He showed that unstimulated interferon gamma is the most sensitive and specific screening test for tuberculous pericarditis. In addition, his IMPI trial showed that adjunctive steroids cause cancer in HIV-infected individuals but reduce constrictive pericarditis and hospitalisations in all patients. This has led to the recommendation for the selective use of adjunctive steroids in HIV-negative individuals alone. These findings resulted in the revision of clinical practice guidelines for tuberculous pericarditis. He reviewed the state of healthcare in South Africa and on the continent and made important recommendations on how health systems could be strengthened to improve the health of all Africans, in particular those in rural and under-served areas.

While the contributions he has made will influence the outcomes of future generations, I believe that his academic career will be remembered most for the relationships he built. He made friends everywhere he went. $\mathrm{He}$ recognised potential and invested substantially in the development of human capacity as part of the academic project. Prof. Mayosi used research to advance his dream of ' $1000 \mathrm{PhDs}$. He wanted to undertake research that would answer the prevailing fundamental questions on African cardiovascular health, and to answer these questions definitively. 
He embarked on building research capacity on the African continent and went into countries with no existing research management infrastructure or ethics committees and helped to set these up ab initio.

His professional achievements and accolades are too many to list, but include the Order of Mapungubwe (Silver) in 2009 and an A-rating by the National Research Foundation. He was a member of the Academy of Science of South Africa and a former President of the College of Physicians of South Africa. In 2017 he was elected to the US National Academy of Medicine (arguably one of the highest honours in the fields of health and medicine, which recognises individuals who have demonstrated outstanding professional achievement and commitment to service). He was instrumental in securing dedicated funding for clinicians from organisations such as Netcare, for the Hamilton Naki Scholarship and the Discovery Academic Fellowships. This culminated in the ' $1000 \mathrm{PhDs}$ in 10 years project' (also known as the National Health Scholars Programme), in collaboration with the Department of Health, the National Health Research Committee, the Public Health Enhancement Fund and the South African Medical Research Council.

As a clinician, he was second to none. He was loved by his patients, who remembered his gentle and impeccable bedside manner. He had a fascination for the understanding of the mechanisms of physical signs, and an encyclopaedic knowledge of clinical medicine. As a researcher, he was a global leader in his field. He published over 350 peer-reviewed articles and book chapters. He had an h-index of 67 and over 40000 citations. $\mathrm{He}$ is one of only a handful of A-rated scientists in South Africa. As a teacher, he was legendary. His knowledge of the cardiovascular system was outstanding. But he was revered by undergraduate students for his approach to his teaching of neurology. He graduated over 30 master's and doctoral students for whom he had provided supervision. All of them will remember him as a caring supervisor who invested substantially in them and created opportunities that have defined their careers. Many of his students have gone on to be leaders in academia, industry and government in this country, on the continent and throughout the world. As a leader, he was awesome. His brand of leadership was honest, full of integrity and characterised by creativity and innovation. His commitment and passion were evident at all times. He is one of the most inspiring people I will ever know. He believed that there was no problem that could not be solved, and his work ethic was unquestionable. He played the long game, and always reminded me: 'A journey of a thousand miles begins with a few steps.' As an advocate, he made seminal contributions to health policy and practice in several important areas. Following appointment by the Academy of Science of South Africa to chair a Consensus Panel on the Revitalisation of Clinical Research and Related Training in South Africa, he published a report in 2009 that has significantly shaped the policy framework on the revitalisation of health research in South Africa. This formed the blueprint of the approach adopted by the government.

How will I remember Prof. Mayosi? I will remember him as a dear friend, mentor and confidant. I will remember him for tireless dedication to advance a great cause. I salute him for a life of integrity, his humility, his outstanding intelligence and his absolute pursuit of knowledge and truth.

How will the Faculty of Health Sciences at UCT and GSH remember him? He will be remembered as the consummate professional and the epitome of hard work. A leader who was exemplary in every fashion. A man with immense dignity and an infectious optimism. A visionary who imagined an Africa capable of driving its own agenda and using science to improve the health of its nations. He will be remembered for his absolute love of the UCT students. His fundamental drive was the transformation of society through investment in future generations of scientists, physicians and future leaders. He will be remembered for his absolute love of the hospital, the Department of Medicine, the Faculty and the University. Both those who knew him well and those who hardly knew him spoke of their absolute love of the man, and their sense of his apparent and evident affection for them. He will be remembered for his unwavering belief in the potential of others and for his excellence in research, and translation of that research into work with a meaningful impact. His ultimate belief was that science should be a vehicle for social and political change, and ultimately a vehicle for economic upliftment. As he often reminded us, 'health comes before wealth'. But, above all, he will be remembered for his absolute love of his family. He was a devoted husband and father and never missed an opportunity to share how much his family meant to him. He spoke often of his gratitude for the support of his wife, and the love he received from his daughters, who he constantly referred to as his 'pride and joy'.

He is survived by his wife, Nonhlanhla, and three daughters, Nosipho, Sivuyile and Camagu (and many other 'daughters' raised in his home) He also leaves behind his mother, Nontle, eldest brother, Sipho, and two sisters, Khuthala and Ncumisa. He will be dearly missed by his family, friends and colleagues. May his soul rest in peace. Lala ngoxolo Rhadebe. Phumla ngoxolo qhawe lamaqhawe. Oko ubuthunywe nguThixo ukugqibile. Umzamo omhle uwenzile. Ugqatso ulifezile!

\section{Rhadebe! Bhungane! Mashwabada! Mthimkhulu! Ndlebentle zombini!}

Acknowledgement. Republished with permission from the South African Medical Journal, the primary source of publication and with which copyright resides. $^{[1]}$

\section{Ntobeko Ntusi}

Department of Medicine, Groote Schuur Hospital and Faculty of Health Sciences, University of Cape Town, South Africa

ntobeko.ntusi@uct.ac.za

\footnotetext{
1. Ntusi N. Professor Bongani Mayosi: A legend in our time. S Afr Med J 2018:108(9):695-696. https://do org/10.7196/SAMJ.2018.v108i9.13584
}

Afr J Health Professions Educ 2018;10(3):143-144. DOI:10.7196/AJHPE.2018.v10i3.115 